\title{
The impacts of intellectual capital on financial performance and value-added of the production evidence from Chile
}

\author{
Christian Acuña-Opazo and Oscar Contreras González \\ Departamento de Ingenieria Industrial, Universidad de La Serena, La Serena, Chile
}

\begin{abstract}
Purpose - The purpose of this paper is to analyse the direct impacts on financial performance and the added value of production in family businesses, considering the efficiency of intellectual capital as determining variables.

Design/methodology/approach - A comparative analysis between family businesses (FB) and nonfamily businesses (NFB) is proposed to explore significant differences in the impacts on financial performance and added value of companies, through multivariate techniques. It contributes to the literature on the family business, and its performance from an analytical framework that incorporates the theory of intellectual capital and the measurement of its impact.

Findings - The findings show that the value-added coefficient of intellectual capital (VAICTM) is a determining factor in the financial performance of companies and, to a greater extent, in the FB than in their NFB counterparts. It is also verified that the efficiency of intellectual capital in the FB has a direct and greater relationship with the value added of production (VAEmp), with respect to non-family businesses, being an important factor in predicting the performance of companies.

Practical implications - The findings allow us to conclude the importance of efficient management of intangible factors in companies, such as intellectual capital, becoming a competitive advantage factor.

Originality/value - The document explores the relationship and impact of VAICTM in family businesses that belong to an emerging economy and demonstrates the existence of differences between FB and NFB, at the level of intangible factors under a comparative analysis.
\end{abstract}

Keywords VAIC, Added value, Family business

Paper type Research paper

\section{Introduction}

The interest in the study and support of intellectual capital has increased, from its definition (Edvinson and Malone, 1997), the proposal of models with financing approach (Brooking, 1996), with corporative strategic approach (Atkinson et al., 1997; Bontis, 1998; Bueno, 2002) and even the consensus of its main components: human capital, structural capital and

(c) Christian Acuña-Opazo and Oscar Contreras González. Published in Journal of Economics, Finance and Administrative Science. Published by Emerald Publishing Limited. This article is published under the Creative Commons Attribution (CC BY 4.0) licence. Anyone may reproduce, distribute, translate and create derivative works of this article (for both commercial and non-commercial purposes), subject to full attribution to the original publication and authors. The full terms of this licence maybe seen at http://creativecommons.org/licences/by/4.0/legalcode

The authors would like to thank the Research and Development Department of University of La Serena for the financial support, as part of the PR18361 project, and the Department of Industrial Engineering at the University of La Serena.

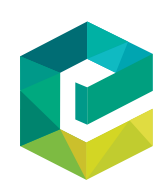

Journal of Economics, Finance and Administrative Science Vol. 26 No. 51, 2021 Vol. 26 No. 51,2021
pp. $127-142$ pp. 127-142 ISSN-L 2077-1886 DOI 10.1108/JEFAS-08-2019-0178 
JEFAS

26,51

relational capital (Bontis, 1998; Edvinsson and Sullivan, 1996; Edvinson and Malone, 1997; Stewart, 1997; Sveiby, 1997; Roos et al., 1998; Bueno-CIC, 2003; Mondal and Ghosh, 2012; Joshi et al., 2013), as well as the interrelation among its elements (Chen et al., 2004; Nazari and Herremans, 2007; Iazzolino and Laise, 2013).

The study of intellectual capital has considered the measurement of the impact on the financial performance of companies (Yalama and Coskun, 2007; Pew Tan et al., 2007; Chu et al., 2011), on the return on investments (Makki and Lodhi, 2009), as well as the performance of companies (Jin and Wu, 2008; Clarke et al., 2011; Maditinos et al., 2011; Mehri et al., 2013). Only some authors have developed studies to determine the relationship, impact and/or effects on the added value of the company. Specifically, Gan and Saleh (2008), tried to explain if efficiency in value creation can be explained by market valuation, profitability and productivity in technology-intensive companies, finding that VAIC ${ }^{\mathrm{TM}}$ components have different impacts on performance compared to the aggregate indicator. A special case is a study by Britto et al. (2014) on real estate companies, who analysed whether the value created by real estate companies can be better evaluated using elements of intellectual capital or traditional performance measures, finding that CI has a significant inverse relationship with the market value of companies. Despite the great evidence of studies on performance and scarce studies on the value-added of companies, there are no records of studies on family businesses (FB), where the impact and/or effects of intellectual capital on the performance of $\mathrm{EF}$, an important issue that this research proposes to analyse.

For some authors, the IC, and the relationship with the groups of interest have an important role in the creation of value (Powell, 2003; Chen et al., 2005) and in a special way in family businesses (Kammerlander et al., 2015), becoming a source of competitive advantages and, therefore, ensures better performance of companies (Razafindrambinina and Kariodimedjo, 2010; Wang, 2012).

In Chile, family businesses represent $90 \%$ of all participating companies in the national economy (Torres et al., 2017), with an approximate contribution of $50 \%$ to GDP and $63 \%$ of employment (Vesna et al., 2015).

Despite the abundant literature on studies about family businesses (FB), that mainly discuss the heterogeneity of FB (Barbera and Moores, 2013) and the differences with nonfamily business (NFB) (Dawson and Mussolino, 2014; Deephouse, and Jaskiewicz, 2013), covering specific areas such as socio-emotional wealth (Berrone et al., 2012; Chua et al., 2015), psychological and social (Jiang et al., 2018), generational succession (Fang et al., 2018), governance (Nordqvist et al., 2014; Le Breton-Miller and Miller, 2018) and financial factors (Kotlar et al., 2018). These are the most studied areas, and few explore the role of intellectual capital in this type of businesses (Grimaldi et al., 2016) and even less focus on its measure and impact on the performance of FB.

Given that intellectual capital has become the strategic factor under the paradigm of competitiveness and has been considered as one of the flexible factors in production, which is relevant when measuring its contribution and efficiency against business production and competitiveness (Dzinkowski, 2000; Marr et al., 2003; Chu et al., 2011). The purpose of this study is to analyse the impact that intellectual capital has on financial performance and the added value of production, through calculations of the VAIC ${ }^{\mathrm{TM}}$ index, in family businesses in the industrial manufacturing sector of Chile. The foregoing is per the proposal by Andreeva and Garanina (2016), who consider more empirical research in emerging markets important and necessary, given that the empirical evidence on the role of the IC in financial performance and organizational competitiveness is still extremely limited. Using a linear econometric model, the impact of the efficiency coefficient of intellectual capital on ROA financial performance and value-added in family businesses will be analysed. The results of 
this research allow us to reduce the gap in the literature on intellectual capital management and studies on family businesses, providing evidence of the impact of this asset on the financial performance and on the added value of family and non-family businesses in Chile.

This study is organized as followed: first, it presents a theoretical framework based on an intentional review of literature about intellectual capital and its measurements in businesses. Then, the methodology is described, showing the data, the variables defined and the models; and, in the following sections, the results and discussion are presented to finally end with the main conclusions.

\section{Theoretical framework}

\subsection{Coefficient of value-added of intellectual capital}

Undoubtedly, the development of competitive advantages is based, among other factors, on the resources of intangible nature (Bontis, 1996; Bueno, 2002), so the generation of wealth and better business performance would be related to the possession and management of these types of resources (Polo and Rodríguez, 2014). In the past few years, the set of tools to measure business performance has increased and all of them have the same goal: the creation of value, so the ultimate goal of business performance analysis and evaluation is the determination of the added value of the companies.

The studies related to the concept of intellectual capital have shown heterogeneity, which can be seen in the studies carried out by Bueno et al. (2008), Monagas-Docasal (2012) and Volkov (2012). Nevertheless, a consensual element of this concept, is that it contributes to improving the performance of businesses (Bueno, 2002) and to the generation of value (Brooking, 1996; Bontis, 1996; Firer and Williams, 2003; Pew Tan et al., 2007; Chu et al., 2011). For Bueno et al. (2008), intellectual capital is an indicator of the organization's wealth derived from the knowledge managed. This will allow the creation of new knowledge and thus the accumulation of greater wealth, creating value to the organization through this intangible asset.

Pulic (1998, 2004) developed a model that allows measuring intellectual capital of a business (VAIC ${ }^{\mathrm{TM}}$ ) based on the efficiency of three components:

(1) Human capital efficiency (HCE), which represents the costs generated by the business employees;

(2) Capital employed efficiency (CEE), which is understood as the financial capital, as to say, the accounting patrimony; and

(3) Structural capital efficiency (SCE), which is understood as the difference between the added value (VA) and the human capital $(\mathrm{CH})$.

Table 1 shows the equations that allow measuring this VAIC $^{\mathrm{TM}}$ index.

The VAIC ${ }^{\mathrm{TM}}$ model has been used by several authors (Dzinkowski, 2000; Marr et al., 2003; Chen et al., 2005; Ghosh and Mondal, 2009; Chu et al., 2011; Joshi et al., 2013; Mehri et al., 2013; Dženopoljac et al., 2016) in determining the impact or/and effects on the performance of companies or businesses, whose motives can be summarized in the following:

- The model VAIC ${ }^{\mathrm{TM}}$ is based on the determination of a low number of variables and simple calculations.

- Despite criticism, the VAIC ${ }^{\mathrm{TM}}$ model delivers consistent information on intellectual capital in organizations.

- The information used to determine the $\mathrm{VAIC}^{\mathrm{TM}}$ coefficient is reliable because it is data present in the financial documents submitted to audits.

Impacts of intellectual capital 


Variable Equation

Value added intellectual coefficient $\left(\right.$ VAIC $^{\text {TM }}$ )

Human capital efficiency (HCE)

$\mathrm{VAIC}=\mathrm{HCE}+\mathrm{SCE}+\mathrm{CEE}$

$\mathrm{HCE}=\mathrm{VA} / \mathrm{HC}$, where:

$\mathrm{HC}$ : costs generated by workers

VA: operating income plus worker

130

costs (wages, benefits and social

security), depreciation, amortization and provisions

Structural capital efficiency (SCE)

$\mathrm{SCE}=\mathrm{SC} / \mathrm{VA}$, where:

Capital employed efficiency (CEE)

SC: gross operating profit

$\mathrm{CEE}=\mathrm{VA} / \mathrm{CE}$, where

CE: financial capital of the company (or equity)

Table 1.

Source: Own elaboration. Based on Pulic (2000)

On the other hand, several authors have carried out research under the methodology of systematic review and bibliometrics (Volkov, 2012; Iazzolino and Laise, 2013), showing limited contribution on the study of intellectual capital about the performance of family businesses (Lunardi et al., 2017).

\subsection{Intellectual capital and financial performance}

According to García (2009, 2003), performance is defined as a measure of productivity, where the resources committed to a business guarantee its permanence and growth, thus, generating value for investors. Growing these resources, which allows increasing the assets of investors, is the purpose of any company (Ittner and Larcker, 2003). Therefore, the measurement of the company's performance becomes relevant, with several indicators for this.

A group of indicators used in most studies (Molina-Parra et al., 2017), correspond to those of effectiveness or productivity, such as, return on assets (ROA) and Return on Equity (ROE) (Rivera and Ruiz, 2011). These indicators measure the ability to generate profits, considering three important factors: the number of assets, their nature (operational or total) and the right to own the resource (equity) (Rivera and Ruiz, 2011; Stern et al., 1995).

However, the intangible nature of some resources or assets makes it difficult to measure the performance of the company using these resources, with intellectual capital being one of them. Given that this asset is not reflected in the financial reports of the businesses (Brooking, 1996; Edvinson and Malone, 1997; Sveiby, 1997; Bueno, 2002), its measurement is essential to analyse its effect on the performance of the businesses (Puntillo, 2009). In this sense, the models developed to measure the intangibles are focused on the economic performance of the business (Sveiby, 2007), showing a shortage of studies that analyse the effect or the impact of the intellectual capital in the business financial performance (Stern et al., 1995; Stewart, 1997; Pulic, 1998; Lev, 1999; Firer and Williams, 2003; Pew Tan et al., 2007; Chu et al., 2011).

Sufficient evidence exists on the use of the VAIC ${ }^{\mathrm{TM}}$ model in financial and banking sectors, measuring the intellectual capital impact over the performance of the businesses (Wei Kiong Ting and Hooi Lean, 2009; Mondal and Ghosh, 2012; Joshi et al., 2013; Al-Musali and Ismail, 2014) and its use is limited in other sectors, except the studies carried out by Zeghal and Maaloul (2010) applied to the high technology sector in Great Britain and the one carried out by Guo et al. (2012) applied to the biotechnology sector, both studies investigated 
the impact of intellectual capital in the financial performance of the businesses. González et al. (2017) also used this model about financial profit, applying it to businesses that quote and belong to the Mexican Industrial Sector, being the human capital the main source of intellectual capital and value creator, resulting in similarity to other studies applied in the financial sector (Goh, 2005; Mondal and Ghosh, 2012).

Most of the studies that analyse the relation between $\mathrm{VAIC}^{\mathrm{TM}}$ components and the financial performance of businesses, use the return on assets (ROA) as a variable of study (Gan and Saleh, 2008; Chu et al., 2011; Mondal and Ghosh, 2012; Joshi et al., 2013; González et al., 2017), stating that there is a positive relationship between financial performance indicators and VAIC ${ }^{\mathrm{TM}}$, while other researches (Chan, 2009; Ghosh and Mondal, 2009), do not show conclusive results about such positive relationship. According to Sveiby (2010), the use of ROA indicator is useful for comparative financial analysis among businesses from the same sector, allowing to perceive the financial value of the intangible assets in a scenario of established accounting and financial standards.

Therefore, the following hypotheses are proposed concerning intellectual capital and financial performance in $\mathrm{FB}$.

H1. In the manufacturing industrial sector, the greater the value-added factor of intellectual capital level (VAIC ${ }^{\mathrm{TM}}$ ), the greater the return on assets (ROA) of the businesses.

H2. In the manufacturing industrial sector, the relationship between the return on assets (ROA) and the value-added factor of intellectual capital (VAIC ${ }^{\mathrm{TM}}$ ), is positive and greater among family businesses than in non-family businesses.

\subsection{Intellectual capital and value-added}

For the Ministry of Economy, Development, and Tourism of Chile, the added value of production is the value of production of companies discounted the value of the products used in their production. Thus, the added value of the production of the companies can be expressed as follows:

$$
\sum \text { Value Added Companies }=\sum \text { Production }-\sum \text { Intermediate Consumption }
$$

The previous expression considers the final value of the production, decomposing in the value added by the companies to the final production and the value coming from the intermediate goods that are also used in this production (Fuentes and García, 2014), avoiding a double accounting in the final value. In this way, it is possible to adapt equation (1), as follows:

$$
\text { Production }(\mathrm{VBP})=\text { Total Income }-\Delta \text { Inventories }
$$

where:

- Total revenues correspond to the income from the main activity of the company, other operating income, plus the variation of stocks or inventories between year $t$ and $t-1$.

- Variation inventories corresponds to the stocks of both finished and in-process products, as well as the existence of raw materials, so it would not be correct to use the total production as a variation. However, because there is no availability of other variables that allow such correction, it is also possible to use it in the production calculation (Chumacero and Fuentes, 2002). 
JEFAS

26,51

For Liang and Yao (2005), net income is the most significant explanatory capacity in the value contributed by the company to the market. On the other hand, intermediate consumption corresponds to the products consumed in the production process without considering taxes, represented by equation (3).

$$
\text { Intermediate Consumption }=\text { Total expenses }- \text { Dependent workers compensation }
$$

\section{2}

where:

Total expenses correspond to sales and/or production costs, energy expenses, communication and ICT service expenses, general expenses, administration and finance expenses.

Following Mosavi et al. (2012), there are two methods to determine the value of a company: First, based on the financial statements of the company, and second, based on its market value, through the stock market. Both values will be different, resulting in a larger amount market value (Chen et al., 2005; Edvinson and Malone, 1997). Among the reasons for such difference between the two values, is the effect of the intellectual capital used by the company and as mentioned, is not present in the financial statements (Brooking, 1996; Edvinson and Malone, 1997; Sveiby, 1997; Good, 2002).

To the extent that companies efficiently manage their intellectual capital, a greater potential for success through the link with the development of competitive advantages and value-added will generate the company to the market (Cañibano et al., 1999), regardless of its typology and nature, for example, family or non-family business.

There are abundant theoretical arguments and empirical background for the competitive advantages and disadvantages of companies, especially family businesses; however, there is still a comprehensive perspective focused on adding value based on intangible factors (Kammerlander et al., 2015). For some authors (Salehi et al., 2014), there is a significant relationship between added value and efficiency of intellectual capital, thereby demonstrating a growth in the performance of companies (Lunardi et al., 2017; Makki and Lodhi, 2008). Therefore, the higher the coefficient of intellectual capital or VAICTM, the more value-added the company will obtain (Mosavi et al., 2012).

Therefore, the following hypotheses are proposed concerning intellectual capital and added value in the FB:

H3. In the manufacturing industrial sector, the relationship between the value-added factor of intellectual capital (VAIC ${ }^{\mathrm{TM}}$ ) and the value added of production (VAEmp), is positive and greater among family businesses than in non-family businesses.

\section{Data and methodology}

In Chile, $48.3 \%$ of the businesses in the country are family ones and under this framework, $48.6 \%$ correspond to SMEs, while $39.8 \%$ correspond to big companies; they generate $60 \%$ of the jobs and contribute to $64.7 \%$ of the GDP (gross domestic product) (Ministerio de Economía de Chile, 2017). The national manufacturing industrial sector represents an essential pillar in the country's growth, not only for the use of resources such as raw materials, energy and capital but also for generating jobs improving productivity and developing productive linkage. Based on data from the World Bank (2016), the Chilean industrial sector has contributed, on average, with $34.8 \%$ of the GDP in the periods of $2010-2016$, concentrating $52 \%$ of the family businesses in the country. Therefore, it is important to study and analyse the added value of the FB in the industrial sector of Chile, as a result of the management of its intellectual capital, which has become an important focus in the generation of competitive advantages. 


\subsection{Database}

The database corresponds to the fourth longitudinal survey of businesses 2016 of Chile (ELE4), with records for the periods of 2014-2015 that represent national statistics based on the activity and size of the businesses (Ministerio de Economía de Chile, 2017). The form design and the methodology used to follow the general guidelines suggested by OECD and Eurostat Community Innovation Survey (CIS), which are embodied in OSLO Manual (OECD/European Communities, 2005). Database corresponds to 8.084 businesses of 13 economic sectors with sales levels above US\$31,594.12 (exchange rate for 31 December 2016).

Therefore, the sample contains 1.198 businesses from the industrial manufacturing sector (Production of food and drinks, Furniture Manufacture, Paper Manufacture, Machinery and Equipment Manufacture and other industrial goods). The presence of an outlier requires prior data processing using the criteria of extreme points from the left side $\mathrm{x}<\mathrm{Q}_{1}-3\left(\mathrm{Q}_{3}-\mathrm{Q}_{1}\right)$, and from the right-side $\mathrm{x}>\mathrm{Q}_{3}+3\left(\mathrm{Q}_{3}-\mathrm{Q}_{1}\right)$. The clean sample finally corresponds to 1.109 businesses.

The family businesses (FB) correspond to $49.53 \%$ of the business of the samples. The criteria used to decide if a business is a family business or not, are (San Martín-Reyna and Durán-Encalada, 2012):

- in the business ownership the participants are mainly (more than $50 \%$ ) a family or a family group; and

- at least one member of the family that owns the business is present in the management of it.

The remaining $50 \%$ corresponds to non-family businesses. Table 2 shows the descriptive summary of the sample.

\subsection{Variables}

The selection of the variables used and indicated in Table 3 are established from OSLO Manual (OECD/European Communities, 2005). The size of the business is used as a control variable, nevertheless, literature is not precise about its use, given that, in an innovation context, SME's suffer from high competition and lack of resources (financial and professional), which results in difficulties for the efficient performance of such process, differently from big businesses (Ko et al., 2008).

The analysis is conducted under the application of the multiple linear regression and the analysis of the statistics of pearson correlation, variance inflation factor (VIF), $t$ test, F test (Pérez, 2004; Hair et al., 2010).

\subsection{Models}

To provide answers to the questions using the analysis of the parameters of the explicative variables, the regression models are presented in Table 4 with their respective

operationalization of the variables.

\begin{tabular}{lrrrrrr}
\hline & \multicolumn{2}{c}{ SMEs } & \multicolumn{2}{c}{ Larger company } & \multicolumn{2}{c}{ Total } \\
\hline Family business (FB) & 266 & $60.32 \%$ & 331 & $46.90 \%$ & 579 & $49.53 \%$ \\
Non-family business (NFB) & 175 & $39.68 \%$ & 355 & $53.10 \%$ & 530 & $50.47 \%$ \\
Total & 441 & $39.75 \%$ & 668 & $60.25 \%$ & 1,109 & $100.00 \%$
\end{tabular}

(Perez, 2004: Hair etal. 2010$)$.

Impacts of intellectual capital

Source: Own elaboration

Table 2. Description of the studied sample, by business type and 


\section{JEFAS 26,51}

\begin{tabular}{lll}
\hline Variable & Measure & Description \\
\hline Value added (VAEmp) & Thousands \$ & Added value in production by companies in 2015
\end{tabular}

\section{(CLP)}

\section{4}

Value added intellectual coefficient (VAIC ${ }^{\mathrm{TM}}$ )

Return on asset (ROA) Size of the company (TamEmp)

Type of the company (TEmpresa)
Thousands $\$$ (CLP)

$(\%)$

Table 3.

Description of the variables
VAEmp $=$ Production - Intermediate Consumption, where:

Production corresponding to the value of the company's production in 2015; and Intermediate Consumption is the value from the intermediate products used by the company in production

Coefficient that measures the efficiency of intellectual capital, based on three variables. $\mathrm{VAICi}=\mathrm{HCEi}+\mathrm{SCEi}+$ CEEi. (Pulic, 2000)

Measures profitability on company assets

1: Company with less than 200 workers or employees, during 2015

0 : Company with more than 200 workers or employees, during 2015

1: FB - If a family or family group participates in the ownership of the company (more than $50 \%$ )

$0: \mathrm{NFB}$ - If a family or a family group participates in the ownership of the company less than $50 \%$

Source: Own elaboration. Based on OSLO Manual (2005) and Public (2000)

Table 4.

Models Equation

$1 \quad \operatorname{LnROA}=\beta_{0}+\beta_{1} \operatorname{LnVAIC}+\beta_{2}$ TamEmp $+\varepsilon$

Regression models Source: Own elaboration

In the calculation of the $\mathrm{VAIC}^{\mathrm{TM}}$ indicator, it will be used the methodology proposed by Pulic (2014) and the one applied by Kujansivu and Lönnqvist (2007) and Laing et al. (2010).

\section{Results}

It is presented in a comparative way, the calculation of the statisticians that allow interfering in the fulfilment of the conditions to determine the different impacts about the performance and added value of the production of the studied businesses. Table 5 corresponds to the correlation matrix (EF and $\mathrm{EnF})$, and it shows that the values indicate an acceptable basis of discriminant validity (Cohen et al., 2014; Kemp, 2003). In this sense, the presence of high significance in all the coefficients of correlation is important. The background about the goodness of fit and statistical independence of regression models that will allow understanding $H 1, H 2, y H 3$ is presented in Table 6 .

Table 7 shows the results of each model, the relation of $\beta$ coefficients and co-linearity diagnosis, according to the type of businesses (FB and NFB).

Table 8 shows the results of the homoscedasticity test and the main indicators of the ANOVA matrix, according to variables of classification: type of businesses (FB versus $\mathrm{NFB}$ ), and the size of the business (TamEmp). 


\begin{tabular}{|c|c|c|c|c|c|c|c|}
\hline & Mean & $\mathrm{SD}$ & VAEmp & $\mathrm{ROA}$ & VAIC & TamEmp & $\begin{array}{l}\text { Impacts of } \\
\text { intellectual }\end{array}$ \\
\hline \multicolumn{7}{|c|}{ Family business (FB) } & \multirow{5}{*}{ capital } \\
\hline VAEmp & 14.482 & 1.607 & \multirow[t]{4}{*}{1} & \multirow{4}{*}{$\begin{array}{l}0.493^{*} \\
1\end{array}$} & \multirow{4}{*}{$\begin{array}{l}0.621^{*} \\
0.754^{* *} \\
1\end{array}$} & \multirow{4}{*}{$\begin{array}{l}-0.674^{* *} \\
0.332^{*} \\
0.056^{*} \\
1\end{array}$} & \\
\hline ROA & -2.456 & 0.992 & & & & & \\
\hline VAIC & 1.160 & 0.667 & & & & & \\
\hline TamEmp & 0.239 & 0.428 & & & & & \\
\hline \multicolumn{7}{|c|}{ Non-family business (NFB) } & \multirow{5}{*}{135} \\
\hline VAEmp & 15.077 & 1.849 & \multirow[t]{4}{*}{1} & \multirow{4}{*}{$\begin{array}{l}0.432^{*} \\
1\end{array}$} & $0.657^{*}$ & \multirow{4}{*}{$\begin{array}{c}-0.697^{* *} \\
0.268^{* *} \\
-0.001^{*} \\
1\end{array}$} & \\
\hline ROA & -2.740 & 1.107 & & & $0.557 * *$ & & \\
\hline VAIC & 1.238 & 0.705 & & & 1 & & \\
\hline TamEmp & 0.154 & 0.362 & & & & & \\
\hline \multirow{2}{*}{\multicolumn{7}{|c|}{$\begin{array}{l}\text { Notes: *The correlation is significant at the } 0.05 \text { level (bilateral). **The correlation is significant at the } 0.01 \\
\text { level (bilateral) } \\
\text { Source: Own elaboration }\end{array}$}} & $\begin{array}{r}\text { and correlation } \\
\text { matrix (Pearson's }\end{array}$ \\
\hline & & & & & & & \\
\hline
\end{tabular}

\begin{tabular}{llcccrcc}
\hline & & & & & \multicolumn{3}{c}{ Statistical independence } \\
Model & Type of the company & $\mathrm{N}$ & $R^{2}$ & $R_{\text {adj. }}^{2}$ & F-test & Sig. & Durbin-Watson \\
\hline 1 & FB & 579 & 0.665 & 0.655 & 15.546 & 0.000 & 1.840 \\
& NFB & 530 & 0.696 & 0.685 & 8.462 & 0.000 & 1.720 \\
2 & FB & 579 & 0.566 & 0.556 & 45.122 & 0.000 & 1.866 \\
& NFB & 530 & 0.592 & 0.582 & 50.987 & 0.000 & 2.200
\end{tabular}

Source: Own elaboration

Table 6.

Regression models Goodness of fit and statistical independence (DW)

\begin{tabular}{|c|c|c|c|c|c|c|c|c|c|c|}
\hline \multirow[b]{2}{*}{ Model } & \multirow[b]{2}{*}{ DV. } & \multirow[b]{2}{*}{ ID. } & \multicolumn{3}{|c|}{$\begin{array}{l}\text { Family business (FB) } \\
\text { Collinearity statistics }\end{array}$} & \multicolumn{5}{|c|}{$\begin{array}{l}\text { Non-family business (NFB) } \\
\text { Collinearity statistics }\end{array}$} \\
\hline & & & $\beta$ & E.T. & Tolerance & FIV & $\beta$ & E.T. & Tolerance & VIF \\
\hline \multirow[t]{3}{*}{1} & ROA & Constant & $-3.040 * * *$ & 0.149 & & & $-3.171^{* * * *}$ & 0.172 & & \\
\hline & & VAIC & $0.351 * *$ & 0.109 & 0.997 & 1.003 & $0.247^{* *}$ & 0.119 & 0.998 & 1.002 \\
\hline & & TamEmp & $0.740^{* * * *}$ & 0.17 & 0.997 & 1.003 & $0.818^{* * * *}$ & 0.230 & 0.988 & 1.004 \\
\hline \multirow[t]{4}{*}{2} & VAEmp & Constant & $14.435 * * *$ & 0.371 & & & $15.121 * * *$ & 0.383 & & \\
\hline & & ROA & $-0.162^{*}$ & 0.104 & 0.834 & 1.199 & $-0.101^{*}$ & 0.100 & 0.904 & 1.106 \\
\hline & & VAIC & 0.198* & 0.146 & 0.934 & 1.070 & $0.174^{*}$ & 0.151 & 0.973 & 1.027 \\
\hline & & TamEmp & $-2.425^{* * *}$ & 0.234 & 0.889 & 1.125 & $-3.473^{* * *}$ & 0.301 & 0.927 & 1.079 \\
\hline
\end{tabular}

Notes: Level of significance (Sig.): $* p<0.05 ; * * p<0.01 ; * * * p<0.001$

Table 7.

Models, coefficients relation and colinearity diagnosis (VIF)

Levene's test allows contrasting the hypothesis of equality of population variance. In this case, the level of significance (Sig.) is greater than 0.05, so the hypothesis of equality of the variance is accepted, concluding that there is homoscedasticity in the variables studied (VAIC ${ }^{\mathrm{TM}}$ y VAEmp). 
JEFAS

26,51

\section{6}

In respect to the analysis of variance, $\mathrm{F}$ statistic in Table 8 allows analysing intragroup significance. In this case, it is observed an $\mathrm{F}$ indicator less than 0.05 , rejecting the hypothesis of equality of means. The exception is produced in the result for the coefficient of the value added of the intellectual capital (VAIC ${ }^{\mathrm{TM}}$ ), where depending on the size of the businesses, is accepted the hypothesis of equality of means; therefore, there are no significant differences between the businesses in relation to such variable (VAIC ${ }^{\mathrm{TM}}$ ).

\section{Discussion}

To validate the models proposed, following Pérez (2004) criteria and Hair et al. (2010), the goodness of fit and the statistic significance, the independence of the residues and the collinearity diagnosis were analysed. In Table 6 , it can be seen that both models present acceptable goodness of fit ( $R^{2}$ and $R^{2}$ adj), consistent with other studies (González et al., 2017; González, 2017; Amin and Aslam, 2017), in addition, DW values in both models are between 1.720 and 2.200 (Table 6); therefore, it can be assured the existence of independence in the explicative variables, validating such assumption. In respect to the existence of any exact relationship among the independent variables, a collinearity diagnosis was carried out using statistical tolerance and VIF. In this sense, it is observed in Table 7 that the values of tolerance are high ( $>0.904)$, which complemented with the values obtained for VIF $(<1.106)$ allows to assure that the variance of the variable is less, and therefore, it makes it possible to ensure that there is no collinearity.

Each model presents a statistic significance (Table 6) according to F test (Sig. $=0.000$ ) following Perez criteria (2004) and Hair et al. (2010). According to the results presented in Table 5, there is a homoscedastic behavior of the variance in the group of businesses studied, as for example the case of the variable value added of production, according to the type of business, that is slightly higher than 0.05 .

In response to each hypothesis, the results for Model 1 (Table 7 ) show a positive and statistically important impact on financial performance (EF: $\beta_{1}=0.351 ; p<0.01 / \mathrm{EnF}: \beta_{1}=$ 0.247; $p<0.01$ ), complemented with the correlation coefficients (Table 5), they allow to empirically demonstrate that the predictors fulfil $H 1\left(H_{1}\right)$. These results are consistent with the ones obtained by other authors (González et al., 2017; Amin and Aslam, 2017; Chu et al., 2011) when pointing that $\mathrm{VAIC}^{\mathrm{TM}}$ is an important predictor and has a positive impact on the financial performance of businesses. In addition, it can be observed in family businesses a $\beta_{1}$ predictor $\left(\beta_{1}=0.351\right)$ that is greater than the one in non-family businesses $\left(\beta_{1}=0.247\right)$ at the same level of significance, which makes $H 2\left(H_{2}\right)$ empirically accepted. These results align with the findings from other authors (Lunardi et al., 2017), where family businesses present better financial results (ROA - ROI) than non-family businesses based on internal and intangible factors, being $\mathrm{FB}$ the most financially conservative ones when facing periods of crisis.

When observing Model 2 (in Table 7) it is evident that VAIC ${ }^{\mathrm{TM}}$ impact over the value added of production (VAEmp) is positive $\left(\beta_{2}=0.198 ; p<0.05 ; \beta_{2}=0.174 ; p<0.05\right)$ and

Table 8.

Homoscedasticity test - ANOVA

\begin{tabular}{lcrrrrrrr}
\hline & \multicolumn{3}{c}{ Variable: VAIC } & \multicolumn{4}{c}{ Variable: VAEmp } \\
& Homocedasticity & \multicolumn{2}{c}{ ANOVA } & \multicolumn{2}{c}{ Homocedasticity } & \multicolumn{2}{c}{ ANOVA } \\
Classification variable & Levene & Sig. & F-test & Sig. & Levene & Sig. & F-test & Sig. \\
\hline Type of the company (FB-NFB) & 0.026 & 0.872 & 12.193 & 0.001 & 3.634 & 0.057 & 7.691 & 0.006 \\
Size of the company (TamEmp) & 1.206 & 0.273 & 0.766 & 0.382 & 0.145 & 0.704 & 420.591 & 0.000 \\
Source: Own elaboration & & & & & & & & \\
\hline
\end{tabular}


indifferent when it comes to the type of businesses (FB and NFB). From the above, it can be seen that the VAIC ${ }^{\mathrm{TM}}$ contribution to the explanation of VAEmp is greater in the family business than in non-family businesses, as to say SME's, although such difference in the impact on the dependent variable is marginal. Considering the group of FBs, family business of great size (big businesses, with more than 200 employees), VAIC ${ }^{\mathrm{TM}}$ contribution to the value-added of productions is greater than the SME's counterpart, possibly explained because of its greater disposition and quality of resources and greater efficiency in its processes. These results are consistent with the ones found by other authors (Lunardi et al., 2017; Makki and Lodhi, 2008; Firer and Stainbank, 2003). The authors decided to accept H3.

With the previous results, it is possible to empirically point that, there are significant differences in the value-added of family businesses of the manufacturing industrial sector, over the non-family businesses. The above is supported by the values presented in Table 8 (ANOVA, F test). The results obtained for the value added of production is significantly greater in the family businesses than in the non-family businesses. As for the value added of the intellectual capital (VAIC ${ }^{\mathrm{TM}}$ ), there are also important statistical differences (analysis of means), between FB and NFB. The previous allows supporting the results found for both groups of businesses, in terms of financial performance and value-added.

\section{Conclusions}

In this work, it has been studied how the intellectual capital, measured with the coefficient of the value-added of the intellectual capital (VAIC ${ }^{\mathrm{TM}}$ ) has an impact on the financial performance and the valued-added of the production of the businesses that belong to the manufacturing industrial sector of an emerging economy. From the analysis of 1,109 businesses using the fourth longitudinal survey of businesses 2016 of Chile (ELE-4), the empirical results establish that the efficiency of the intellectual capital affects positively the financial performance, showing a greater impact on family businesses than on non-family businesses, especially when it comes to SMEs.

The study shows significantly that the VAIC ${ }^{\mathrm{TM}}$ coefficient produces a greater impact on the value-added of the production in family businesses, and such differences, with respect to the non-family business are important.

With the results obtained, it is possible to conclude that the coefficient of the value added of the intellectual capital (VAIC ${ }^{\mathrm{TM}}$ ) is an important predictor of the financial performance and the valued-added of the businesses, so its management will allow to strengthen the competitive advantages, improve the organizational efficiency and increase the development and growth of the business.

Finally, this work has implications for entrepreneurs, business managers and capital management managers by showing that there are internal and intangible factors that affect the businesses results (financial and production); therefore, it is advisable to pay special attention to them when establishing business strategies, especially the ones based on innovation processes.

\section{References}

Al-Musali, M.A.K. and Ismail, K.N.I.K. (2014), "Intellectual capital and its effect on financial performance of banks: evidence from Saudi Arabia", Procedia - Social and Behavioral Sciences, Vol. 164, pp. 201-207.

Amin, S. and Aslam, S. (2017), "Intellectual capital, innovation and firm performance of pharmaceuticals: a study of the London stock exchange", Journal of Information and Knowledge Management, Vol. 16 No. 2, p. 1750017. 
JEFAS
26,51

138

Andreeva, T. and Garanina, T. (2016), "Do all elements of intellectual capital matter for organizational performance? Evidence from Russian context”, Journal of Intellectual Capital, Vol. 17 No. 2, pp. 397-412.

Atkinson, A.A., Waterhouse, J.H. and Wells, R.B. (1997), "A stakeholder approach to strategic performance measurement”, MIT Sloan Management Review, Vol. 38 No. 3, p. 25.

Barbera, F. and Moores, K. (2013), "Firm ownership and productivity: a study of family and non-family SMEs”, Small Business Economics, Vol. 40 No. 4, pp. 953-976.

Berrone, P., Cruz, C. and Gómez-Mejía, L.R. (2012), "Socioemotional wealth in family firms: theoretical dimensions, assessment approaches, and agenda for future research", Family Business Review, Vol. 25 No. 3, pp. 258-279.

Bontis, N. (1996), "There's a price on your head: managing intellectual capital strategically", Business Quarterly, Vol. 60 No. 4, pp. 40-78.

Bontis, N. (1998), "Intellectual Capital: an exploratory study that develops measures and models", Management Decision, Vol. 36 No. 2, pp. 63-76.

Brooking, A. (1996), El Capital Intelectual: el Principal Activo de Las Empresas Del Tercer Milenio, Edtorial Paidós, Barcelona.

Bueno, E. (2002), "Dirección estratégica basada en conocimiento: Teoría y práctica de la nueva perspectiva", en Morcillo, P. y Fernández Aguado, J. (Eds), Nuevas Claves para la Dirección Estratégica, Barcelona.

Bueno-CIC (2003), "Intellectus Model. Model for the measurement and management of intellectual capital", Doc. Intellectus, No. 5, CIC-IADE (uam), Madrid.

Bueno, E., Salmador, M.P. and Merino, C. (2008), "Génesis, concepto y desarrollo del capital intelectual en la economía del conocimiento: una reflexión sobre el modelo intellectus y sus aplicaciones", Estudios de Economía Aplicada, Vol. 26 No. 2, pp. 43-63.

Cañibano, L., Covarsi, M.G.A. and Sánchez, M.P. (1999), "La relevancia de los intangibles Para la valoración y la gestión de empresas: revisión de la literatura", Revista Española de Financiación y Contabilidad, pp. 17-88.

Chan, H.K. (2009), "Impact of intellectual Capital on organisational performance: an empirical study of companies in the Hang Seng index (part 1)", The Learning Organization, Vol. 16 No. 1, pp. 4-21.

Chen, J., Zhu, Z. and Yuan Xie, H. (2004), "Measuring intellectual capital: a new model and empirical study", Journal of Intellectual Capital, Vol. 5 No. 1, pp. 195-212.

Chen, M.C., Cheng, S.J. and Hwang, Y. (2005), "An empirical investigation of the relationship between intellectual capital and firms' market value and financial performance", Journal of Intellectual Capital, Vol. 6 No. 2.

Chu, S.K.W., Chan, K.H., Yu, K.Y., Ng, H.T. and Wong, W.K. (2011), "An empirical study of the impact of intellectual capital on business performance", Journal of Information and Knowledge Management, Vol. 10 No. 1, pp. 11-21.

Chua, J.H., Chrisman, J.J. and De Massis, A. (2015), “A closer look at socioemotional wealth: its flows, stocks, and prospects for moving forward”, Entrepreneurship Theory and Practice, Vol. 39 No. 2, pp. 173-182.

Chumacero, R.y. and Fuentes, J.R. (2002), "On the determinants of the Chilean economic growth", Working Paper $\mathrm{N}^{\circ} 134$, Central Bank of Chile.

Clarke, M., Seng, D. and Whiting, R.H. (2011), "Intellectual capital and firm performance in Australia", Journal of Intellectual Capital, Vol. 12 No. 4, pp. 505-530.

Cohen, P., West, S.G. and Aiken, L.S. (2014), Applied Multiple Regression/Correlation Analysis for the Behavioral Sciences, Psychology Press.

Dawson, A. and Mussolino, D. (2014), "Exploring what makes family firms different: discrete or overlapping constructs in the literature?", Journal of Family Business Strategy, Vol. 5 No. 2, pp. 169-183. 
Deephouse, D.L. and Jaskiewicz, P. (2013), "Do family firms have better reputations than non-family firms? An integration of socioemotional wealth and social identity theories", Journal of Management Studies, Vol. 50 No. 3, pp. 337-360.

Dženopoljac, V., Janoševic, S. and Bontis, N. (2016), "Intellectual capital and financial performance in the Serbian ICT industry”, Journal of Intellectual Capital, Vol. 17 No. 2, pp. 373-396.

Dzinkowski, R. (2000), "The measurement and management of intellectual capital: an introduction", Management Accounting: Magazine for Chartered Management Accountants, Vol. 78 No. 2, pp. 32-35.

Edvinson, L. and Malone, M. (1997), Intellectual Capital: Realizing Your Company's True Value by Finding its Hidden Brainpower, HarperBusiness, New York.

Edvinsson, L. and Sullivan, P. (1996), "Developing a model for management intellectual capital", European Management Journal, Vol. 14 No. 4, pp. 187-199.

Fang, H., Kotlar, J., Memili, E., Chrisman, J.J. and De Massis, A. (2018), “The pursuit of international opportunities in family firms: generational differences and the role of knowledge-based resources", Global Strategy Journal, Vol. 8 No. 1, pp. 136-157.

Firer, S. and Stainbank, L. (2003), "Testing the relationship between intellectual capital and a company's performance: evidence from South Africa”, Meditari Accountancy Research, Vol. 11 No. 1, pp. 25-44.

Firer, S. and Williams, S. (2003), "Intellectual capital and traditional measures of corporate performance", Journal of Intellectual Capital, Vol. 4 No. 3, pp. 348-360.

Fuentes, R.y. and García, G. (2014), "Una mirada desagregada del deterioro de la productividad en Chile: ¿existe cambio estructural?”, Economía Chilena, Vol. 17 No. 1, Abril 2014.

Gan, K. and Saleh, Z. (2008), "Intellectual Capital and corporate performance of technology-intensive companies: Malaysia evidence", Asian Journal of Business and Accounting, Vol. 1 No. 1, pp. 113-130.

García, O. (2003), Valoración de Empresas, Gerencia de Valor y EVA, Prensa Moderna Impresores SA, Cali.

García, O. (2009), Administración Financiera: Fundamentos y Aplicaciones, 4th ed., Prensa Moderna Impresores SA, Cali.

Ghosh, S. and Mondal, A. (2009), "Indian software and pharmaceutical sector IC and financial performance", Journal of Intellectual Capital, Vol. 10 No. 3, pp. 369-388.

Goh, P.C. (2005), "Intellectual capital performance of commercial banks in Malaysia", Journal of Intellectual Capital, Vol. 6 No. 3, pp. 385-396.

González, E.V., Calzada, M.A.H. and Hernández, B.C.S. (2017), "Mexico’s industrial sector companies: a measurement of intellectual capital and its impact on financial performance", Accounting and Management, Vol. 62 No. 1, pp. 184-206.

González, P. (2017), "Una propuesta Para medir la creación de valor por parte del capital intelectual en grandes empresas colombianas", Harvard Deusto Business Research, Vol. 6 No. 1, pp. 3-16. (Special Issue).

Grimaldi, M., Cricelli, L. and Greco, M. (2016), "Perceived benefits and costs of intellectual capital in small family firms", Journal of Intellectual Capital, Vol. 17 No. 2, pp. 351-372.

Guo, W.C., Shiah-Hou, S.R. and Chien, W.J. (2012), "A study on intellectual capital and firm performance in biotech companies", Applied Economics Letters, Vol. 19 No. 16, pp. 1603-1608.

Hair, Jr, Joseph, F., Black, W.C., Barry, B.J. and Anderson, R.E. (2010), Multivariate Data Analysis, 7th ed., Prentice Hall, Upper Saddle River, NJ.

Iazzolino, G. and Laise, D. (2013), "Value added intellectual coefficient (VAIC). a methodological and critical review", Journal of Intellectual Capital, Vol. 14 No. 4, pp. 547-563.

Ittner, C.D. and Larcker, D.F. (2003), "Coming up short on nonfinancial performance measurement", Harvard Business Review, Vol. 81 No. 11, pp. 88-95. 

review and future directions for the social psychology of socioemotional wealth", Family Business Review, Vol. 31 No. 1, pp. 125-157.

Jin, S. and Wu, Y. (2008), “The contribution of intellectual capital to firms' sustainable growth ability: an empirical investigation based on listed companies in china", Paper presented at the Proceedings of the International Conference on Information Management Proceedings of the International Conference on Information Management, Innovation Management and Industrial Engineering, ICIII 2008, Vol. 1, pp. 394-397.

Joshi, M., Cahill, D., Sidhu, J. and Kansal, M. (2013), "Intellectual capital and financial performance: an evaluation of the Australian financial sector", Journal of Intellectual Capital, Vol. 14 No. 2, pp. 264-285.

Kammerlander, N., Sieger, P., Voordeckers, W. and Zellweger, T. (2015), "Value creation in family firms: a model of fit", Journal of Family Business Strategy, Vol. 6 No. 2, pp. 63-72.

Kemp, F. (2003), “Applied multiple regression/correlation analysis for the behavioral sciences”, Journal of the Royal Statistical Society: Series D (the Statistician), Vol. 52 No. 4, pp. 691-691.

Ko, E., Kim, S.H., Kim, M. and Woo, J.Y. (2008), "Organizational characteristics and the CRM adoption process”, Journal of Business Research, Vol. 61 No. 1, pp. 65-74.

Kotlar, J., Signori, A., De Massis, A. and Vismara, S. (2018), "Financial wealth, socioemotional wealth, and IPO underpricing in family firms: a two-stage gamble model", Academy of Management Journal, Vol. 61 No. 3, pp. 1073-1099.

Kujansivu, P. and Lönnqvist, A. (2007), "Investigating the value and efficiency of intellectual capital", Journal of Intellectual Capital, Vol. 8 No. 2, pp. 272-287.

Laing, G., Dunn, J. and Hughes-Lucas, S. (2010), “Applying the VAIC ${ }^{\mathrm{TM}}$ model to Australian hotels", Journal of Intellectual Capital, Vol. 11 No. 3, pp. 269-283.

Le Breton-Miller, I. and Miller, D. (2018), "Looking back at and forward from: 'family governance and firm performance: agency, stewardship, and capabilities”, Family Business Review, Vol. 31 No. 2, pp. 229-237.

Lev, B. (1999), "Seeing is believing: a better approach to estimating knowledge capital", CFO magazine.

Liang, C.J. and Yao, M.L. (2005), "The value-relevance of financial and nonfinancial information: evidence from Taiwan information electronics industry", Review of Quantitative Finance and Accounting, Vol. 24 No. 2, pp. 135-157.

Lunardi, M.A., Barbosa, E.T., Junior, M.M.R., da Silva, T.P. and Nakamura, W.T. (2017), "Criação de valor no desempenho econômico de empresas familiares e não familiares brasileiras", Revista Evidenciação Contábil and Finanças, Vol. 5 No. 1, pp. 94-112.

Maditinos, D., Chatzoudes, D., Tsairidis, C. and Theriou, G. (2011), “The impact of intellectual capital on firm's market value and financial performance", Journal of Intellectual Capital, Vol. 12 No. 1, pp. 132-151.

Makki, M.A.M. and Lodhi, S.A. (2008), "Impact of intellectual capital efficiency on profitability (a case study of LSE25 companies)", The Lahore Journal of Economics, Vol. 13 No. 2, pp. 81-98.

Makki, M.A.M. and Lodhi, S.A. (2009), "Impact of intellectual capital on return on investment in Pakistani corporate sector", Australian Journal of Basic and Applied Sciences, Vol. 3 No. 3, pp. 2995-3007.

Marr, B., Gray, D. and Neely, A. (2003), "Why do firms measure their intellectual capital?”, Journal of Intellectual Capital, Vol. 4 No. 4, pp. 441-464.

Mehri, M., Umar, M.S., Saeidi, P., Hekmat, R.K. and Naslmosavi, S.H. (2013), "Intellectual capital and firm performance of high intangible intensive industries: Malaysia evidence", Asian Social Science, Vol. 9 No. 9, pp. 146-155.

Ministerio de Economía de Chile (2017), "Cuarta encuesta longitudinal empresarial de empresas (ELE4), 2014-2015”, available at: www.economia.gob.cl/estudios-y-encuestas/encuestas/encuestas-de-empren dimiento-y-mpresas/cuarta-encuesta-longitudinal-de-empresas-ele-4 (accessed 24 November 2017). 
Molina-Parra, P.A., Botero-Botero, S. and Montoya-Restrepo, A. (2017), "Estudios de rendimiento en las empresas de familia. Una nueva perspectiva”, Estudios Gerenciales, Vol. 33 No. 142, pp. 76-86.

Monagas-Docasal, M. (2012), "El Capital intelectual y la gestión del conocimiento", Ingeniería Industrial, Vol. 33 No. 2, pp. 142-150.

Mondal, A. and Ghosh, S.K. (2012), "Intellectual capital and financial performance of Indian banks", Journal of Intellectual Capital, Vol. 13 No. 4, pp. 515-530.

Mosavi, S.A., Nekoueizadeh, S. and Ghaedi, M. (2012), "A study of relations between intellectual capital components, market value and finance performance”, African Journal of Business Management, Vol. 6 No. 4, pp. 1396-1403.

Nazari, J.A. and Herremans, I.M. (2007), "Extended VAIC model: measuring intellectual capital components", Journal of Intellectual Capital, Vol. 8 No. 4.

Nordqvist, M., Sharma, P. and Chirico, F. (2014), "Family firm heterogeneity and governance: a configuration approach", Journal of Small Business Management, Vol. 52 No. 2, pp. 192-209.

OECD/European Communities (2005), Oslo Manual: Guideliness for Collecting and Interpreting Innovation Data, OECD.

Pérez, C. (2004), Técnicas de Análisis Multivariante de Datos. Aplicaciones Con SPSS. Editorial Pearson, Prentice Hall, Madrid.

Pew Tan, H., Plowman, D. and Hancock, P. (2007), "Intellectual capital and financial returns of companies", Journal of Intellectual Capital, Vol. 8 No. 1, pp. 76-95.

Polo, F.C. and Rodríguez, C.R. (2014), "Una revisión histórico-descriptiva de las empresas pioneras en el tratamiento de intangibles", Intangible Capital, Vol. 10 No. 1, pp. 125-154.

Powell, S. (2003), "Accounting for intangible assets: current requirements, key players and future directions", European Accounting Review, Vol. 12 No. 4, pp. 797-811.

Pulic, A. (1998), "Measuring the performance of intellectual potential in knowledge economy", 2nd McMaster Word Congress on Measuring and Managing Intellectual Capital by the Austrian Team for Intellectual Potential, pp. 1-20.

Pulic, A. (2000), "VAIC ${ }^{\mathrm{TM}}$ - an accounting tool for IC management", International Journal of Technology Management, Vol. 20 Nos 5/6/7/8, pp. 702-714.

Pulic, A. (2004), "Intellectual capital - does it create or destroy value", Measuring Business Excellence, Vol. 8 No. 1, pp. $62-68$.

Puntillo, P. (2009), "Intellectual Capital and business performance. Evidence from Italian banking industry", Electronic Journal of Corporate Finance, Vol. 4 No. 12, pp. 97-115.

Razafindrambinina, D. and Kariodimedjo, D. (2010), "Intellectual capital and its impacts on corporate social responsibility: findings from Indonesia”, Business Transformation through Innovation and Knowledge Management: An Academic Perspective-Proceedings of the 14th International Business Information Management Association Conference, IBIMA, Vol. 1, pp. 496-512.

Rivera, J.y. and Ruiz, D. (2011), "Análisis del desempeño financiero de empresas innovadoras del sector alimentos y bebidas en Colombia”, Pensamiento and Gestión, Vol. 31, pp. 109-136.

Roos, J., Edvinsson, L. and Dragonetti, N.C. (1998), Intellectual Capital: Navigating the New Business Landscape, Springer, New York, NY University Press, ISBN:0814775128.

San Martín-Reyna, J.M. and Durán-Encalada, J. (2012), "The relationship among business, corporate governance and firm performance: evidence from the Mexican stock exchange", Journal of Family Business Strategy, Vol. 3, pp. 106-117.

Stern, J.M., Stewart, G.B., III and Chew, D.H. (1995), “The EVA® financial management system”, Journal of Applied Corporate Finance, Vol. 8 No. 2, pp. 32-46.

Stewart, T.A. (1997), Intellectual Capital: The New Wealth of Organizations, Bantam Doubleday Dell Publishing Group, New York, NY.

Impacts of intellectual capital 
JEFAS

26,51

Sveiby, K.E. (1997), The New Organizational Wealth: Managing and Measuring Knowledge-Based Assets, Berrett-Koehler Publishers.

Sveiby, K.E. (2010), "Methods for measuring intangible assets", available at: www.sveiby.com/article/ Methods-for-Measuring-Intangible-Assets (accessed 15 March 2018).

Torres, J.P., Bertín, M.J. and López-Iturriaga, F.J. (2017), “Corporate control and firm value: the bright side of business groups”, Journal of Family Business Strategy, Vol. 8 No. 2, pp. 99-108.

Vesna, M., Jiménez, G., Arriagada, V. and Echeverría, C. (2015), Radiografía de la Empresa Familiar en Chile (No. 13), Universidad del Desarrollo, School of Business and Economics.

Volkov, A. (2012), "Value added intellectual Co-efficient (VAIC (TM)): a selective thematicbibliography", Journal of New Business Ideas and Trends, Vol. 10 No. 1, pp. 14-24.

Wei Kiong Ting, I. and Hooi Lean, H. (2009), "Intellectual capital performance of financial institutions in Malaysia”, Journal of Intellectual Capital, Vol. 10 No. 4, pp. 588-599.

Yalama, A. and Coskun, M. (2007), "Intellectual capital performance of quoted banks on the Istanbul stock exchange market”, Journal of Intellectual Capital, Vol. 8 No. 2, pp. 256-271.

Zeghal, D. and Maaloul, A. (2010), "Analysing value added as an indicator of intellectual capital and its consequences on company performance", Journal of Intellectual Capital, Vol. 11 No. 1, pp. 39-60.

\section{Further reading}

Campos, E.B. (2002), "Dirección estratégica basada en conocimiento: teoría y práctica de la nueva perspectiva”, En Nuevas Claves para la Dirección Estratégica, pp. 91-116.

Kai Wah Chu, S., Hang Chan, K. and Wu, W.W. (2011), "Charting intellectual capital performance of the gateway to China", Journal of Intellectual Capital, Vol. 12 No. 2, pp. 249-276.

\section{Corresponding author}

Christian Acuña-Opazo can be contacted at: cacuna@userena.cl

For instructions on how to order reprints of this article, please visit our website: 